\title{
Carbon-coated mesoporous silica functionalized with sulfonic acid groups and its application to acetalization
}

\author{
FANG Lin, ZHANG Kun\#, CHEN Lu, WU Peng* \\ Shanghai Key Laboratory of Green Chemistry and Chemical Processes, Department of Chemistry, East China Normal University, Shanghai 200062 , \\ China
}

A R T I C L E I N F 0

Article history:

Received 29 December 2012

Accepted 20 March 2013

Published 20 May 2013

\section{Keywords:}

Solid acid

Mesoporous carbon

Sulfonic acid group

Acetalization

\begin{abstract}
A B S T R A C T
The inner surface of mesoporous silica SBA-15 was coated by a homogeneous polycyclic carbon layer through controlled carbonization of furfuryl alcohol. The composite was subsequently functionalized with sulfonic acid $\left(-\mathrm{SO}_{3} \mathrm{H}\right)$ groups to form a strong solid acid material, with a tunable acid site density in the range of $0.38-0.84 \mathrm{mmol} / \mathrm{g}$ by varying the thickness of the carbon layer. Structur$\mathrm{al}$ analysis and reaction data revealed that the solid acid catalyst exhibited high reactivity towards the acetalization of aldehydes or ketones with alcohols because of the uniform carbon coating of the mesopores, high acid site density, and its mechanical stability.
\end{abstract}

(C) 2013, Dalian Institute of Chemical Physics, Chinese Academy of Sciences. Published by Elsevier B.V. All rights reserved.

\section{Introduction}

Solid acid catalysts have been widely applied in petroleum refining and fine chemical production processes because of a number of advantages, including their convenient reuse, long-term activities, and low environmental pollution. Solid acids such as metal oxides [1,2], heteropoly acids [3,4], sulfonic acid group-functionalized materials [5,6], and acidic ion exchange resins $[7,8]$ can effectively replace homogeneous acids, including sulfuric acid, fatty acid salts [9], and organic sulfonic acid [10], in various acid-catalyzed reactions, such as the Beckmann rearrangement [11,12], alkylation [13], esterification and hydrolysis [5,6], acylation [14], etherification [15], addition reaction of the epoxides and olefin adducts as well as the dehydration of the alcohols $[16,17]$, condensation $[18,19]$, and hydrogenation reforming [20].

Recently, heterogeneous acids containing sulfonic acid groups, including ionic liquids [21], organic-inorganic hybrid porous materials [22,23] and sugar derived carbon catalysts [24], have been intensively investigated, because of their abundant acid content and effective activities. Xing et al. [25] reported a sulfonated mesoporous carbon material with a classical CMK-3 type mesostructure, applying SBA-15 as a hard template filled with sucrose, which was subsequently carbonized incompletely to a polycyclic aromatic carbon. The aromatic system is rich in benzene rings that can be controllably grafted by sulfonic acid groups, leading to a novel mesoporous solid acid $\mathrm{CMK}-3-\mathrm{SO}_{3} \mathrm{H}$. Compared with the sulfonated sugar carbon acid ( $2 \mathrm{~m}^{2} / \mathrm{g}$ ) from Nakajima et al. [26], it possesses a large specific surface area of nearly $1000 \mathrm{~m}^{2} / \mathrm{g}$ and $1.0 \mathrm{mmol} / \mathrm{g}$ Brönsted acid sites and shows an excellent catalytic activity towards the liquid phase Beckmann rearrangement. However, the carbon framework of $\mathrm{CMK}-3-\mathrm{SO}_{3} \mathrm{H}$ is fragile in practical applications, especially during sulfonation because the frame-

\footnotetext{
*Corresponding author. Tel: +86-21-62232292; Fax: +86-21-62232292; E-mail: pwu@chem.ecnu.edu.cn

\#Corresponding author. Tel: +86-21-62232753; Fax: +86-21-62232753; E-mail: kzhang@chem.ecnu.edu.cn

This work was supported by the National Natural Science Foundation of China (220925310, 21003050, U1162102), the National Key Technology R\&D Program (2012BAE05B02), and the Shanghai Leading Academic Discipline Project (B409). 
work tends to collapse with over-carbonation by the sulfuric acid. Accordingly, Fang et al. [6] further simplified the synthetic procedure to make a sulfonic functionalized carbon-silicon composite, which exhibited high stability and chemical reactivity for esterification and transesterification in biodiesel synthesis after several recycles because of pillaring of silica in the composites. Increasing the carbon loading in a carbon-silica composite can provide more benzene rings for functionalization by sulfonic acid groups but, nevertheless, the bulk aromatic carbon is randomly distributed in the pores or on the channel entrance of SBA-15, which significantly limits the diffusion of large molecules in confined nanospaces.

As is well known, acetalization is generally used to protect the carbonyl group of aldehydes and ketones and, moreover, the acetal is the main raw enantiomeric compound used in the production of anabolic steroids, pharmaceuticals, paint, and perfumes, which often involves large molecules. The reaction is usually catalyzed by homogeneous acids to obtain high yield and selectivity [27]. Although heteropoly acids [21] and ionic liquid catalysts give high yields, greater than $90 \%$, long reaction times are necessary because of their low acidity [28]. Sulfonated nano silica fibers with high acidity are a good candidate; however, their low surface area and small pore volume dramatically reduce the reaction rate [29].

Here, based on a method to synthesize CMK-5 with furfuryl alcohol [30], we prepared a carbon-silica composite with an aromatic carbon layer decoration on the pore walls of mesoporous silica, using furfuryl alcohol as the carbon source. A SBA-15 silica support was pretreated by incorporation of $\mathrm{Al}^{3+}$, which modifies the silica wall with a dispersion of acid sites that then catalyze the carbonization of furfuryl alcohol. The resultant Al-SBA-15 was loaded by furfuryl alcohol, which was then converted to a polycyclic benzene ring carbon coating on the silica wall under a sequence of vacuum extraction and appropriate thermal treatment. Finally, the composite was sulfonated to obtain a mesoporous carbon-silica solid acid, reserving the hollow channels to retain a large surface area and accessible acid sites. This material exhibits a high catalytic reactivity towards the acetalization of aldehydes or ketones with alcohol and is stable during recycled usage.

\section{Experimental}

\subsection{Material preparation}

Mesoporous SBA-15 was synthesized by the conventional approach using poly(ethyleneoxide)-poly(propyleneoxide)poly(ethyl-eneoxide) (P123, $M_{\mathrm{w}} \approx 5800$, Sigma-Aldrich) and tetraethyl orthosilicate (TEOS, Sigma-Aldrich) in acidic media [6]. One gram of calcined SBA-15 was treated with $\mathrm{Al}^{3+}$ in a 25 $\mathrm{ml}$ anhydrous alcohol (China National Medicines Corporation Ltd.) solution containing $0.12 \mathrm{~g} \mathrm{AlCl}_{3}$ (China National Medicines Corporation Ltd.) at a Si/Al molar ratio of 20:1 [31]. After stirring at room temperature for $14 \mathrm{~h}$, the Al-incorporated SBA-15 was filtered, washed three times with anhydrous alcohol, and then dried at $80{ }^{\circ} \mathrm{C}$, followed by calcination at $550{ }^{\circ} \mathrm{C}$ in air for 6 h. The resultant white solid product was named Al-SBA-15 and had a Si/Al molar ratio of 19.2, determined by elemental analysis.

Subsequently, the aluminosilicate was filled with furfuryl alcohol ( $>98.0 \%$, China National Medicines Corporation Ltd.) at room temperature using an incipient wetness method. The amount of furfuryl alcohol was varied over a furfuryl alcohol/Al-SBA-15 mass ratio of 0.5-5, respectively. The filled aluminosilicate was heated at $80^{\circ} \mathrm{C}$ for $1 \mathrm{~h}$ to polymerize the furfuryl alcohol and then exposed to extraction under vacuum at the same temperature for $1 \mathrm{~h}$ to remove the excess alcohol. Finally, calcination was continued under $\mathrm{N}_{2}$ at $550{ }^{\circ} \mathrm{C}$ for $6 \mathrm{~h}$ to obtain the carbon-silica composite, which was named SC- $x(x=$ mass change due to the carbon compound according to the thermogravimetric analysis profile, e.g. $x=15$ indicates a $15 \%$ mass change). The SC- $x$ was mildly sulfonated at $80{ }^{\circ} \mathrm{C}$ in an atmosphere of fuming sulfuric acid $\left(50 \% \mathrm{SO}_{3} / \mathrm{H}_{2} \mathrm{SO}_{4}\right.$, China National Medicines Corporation Ltd.), with a ratio of solid/liquid $=1: 20 \mathrm{~g} / \mathrm{ml}$ for $12 \mathrm{~h}$. To extract the physically adsorbed $-\mathrm{SO}_{3} \mathrm{H}$ group, the solid acid was finally washed with water at $>80{ }^{\circ} \mathrm{C}$ until no white precipitate could be detected in the filtrate with $\mathrm{BaCl}_{2}$ ( $\geq 98.0 \%$, China National Medicines Corporation Ltd.), and dried to obtain the surfonated carbon-silica composite $\mathrm{SC}-x-\mathrm{SO}_{3} \mathrm{H}$.

The SC- $x$ and SC- $x-\mathrm{SO}_{3} \mathrm{H}$ were liberated from the silica template by treatment with $15 \%$ HF ( $\geq 40 \%$, China National Medicines Corporation Ltd.) solution at a ratio of solid/liquid $=1: 20$ $\mathrm{g} / \mathrm{ml}$ under stirring at room temperature overnight, followed by washing with ionized water and drying to obtain CMK-5 type materials, named $\mathrm{C}-x$ and $\mathrm{C}-x-\mathrm{SO}_{3} \mathrm{H}$, respectively.

Sulfonated carbon-silica composites using sucrose were prepared according to the method reported by Fang et al. [6].

\subsection{Characterization}

Powder X-ray diffraction (XRD) patterns were collected on a Bruker D8 ADVANCE instrument using $\mathrm{Cu}-K_{\alpha}$ radiation $(\lambda=$ $0.15406 \mathrm{~nm}$ ). $\mathrm{N}_{2}$ adsorption isotherms were measured at -196 ${ }^{\circ} \mathrm{C}$ on a Quantachrome Autosorb-3B instrument after activating the sample at $120{ }^{\circ} \mathrm{C}$ under vacuum for $6 \mathrm{~h}$. Scanning electron microscopy (SEM) images were obtained with a Hitachi S-4800 microscope. Fourier transform infrared (FT-IR) spectra were recorded on a Nicolet Fourier transform infrared spectrometer (NEXUS 670) using KBr. The spectra of pyridine adsorption were measured by first treating the sample wafers at $150{ }^{\circ} \mathrm{C}$ under vacuum for $5 \mathrm{~h}$ and then exposing them to pyridine vapor at $110^{\circ} \mathrm{C}$ for $0.5 \mathrm{~h}$. Desorption of pyridine was carried out at $150{ }^{\circ} \mathrm{C}$. Thermogravimetric (TG) analysis curves were obtained on a Mettler analyzer (TGA/SDTA 851e/5FL1100). The acid density was quantified by acid-base titration whereby $0.15 \pm 0.01 \mathrm{~g}$ solid acid was ion-exchanged in $60 \mathrm{ml}$ saturated $\mathrm{NaCl}$ solution at room temperature for $12 \mathrm{~h}$ and then filtered, followed by titration of the filtrate against $\mathrm{NaOH}$ solution, which had been standardized by potassium acid phthalate.

\subsection{Catalytic test}

The aldehyde or ketone $0.04 \mathrm{~mol}$, alcohol $0.048 \mathrm{~mol}$ (cyclo- 
hexanone, cyclopentanone, iso-valeraldehyde, iso-butyraldehyde, 3-pentanone, ethylene glycol, and 1,4-butanediol were from China National Medicines Corporation Ltd.; benzaldehyde, 3-Methyl butanal, and diphenyl ketone were from TCI supplier), catalysts (40 mg), and $5 \mathrm{ml}$ of cyclohexane (> 99.5\%, China National Medicines Corporation Ltd.) were placed in a $100 \mathrm{ml}$ three-necked flask and mixed. The flask was connected to a condenser and a trap to the remove the water product by azeotropic distillation. After reacting at $90{ }^{\circ} \mathrm{C}$ under reflux for $1 \mathrm{~h}$, the products were analyzed on an Agilent 6890/5973N gas chromatography-mass spectrometer (GC-MS) and quantified on a Shimadzu 14B FID GC with a DB-WAX capillary column $(\phi 0.25 \mathrm{~mm} \times 30 \mathrm{~m})$ using eicosane as an internal standard.

\section{Results and discussion}

\subsection{Structure and chemical properties of catalyst}

It has been reported that sulfonic group can be induced to a greater extent by increasing the loading of polycyclic benzene rings in SBA-15 [6]. Therefore, the relevance of sulfonate group content and carbon content in the $\mathrm{SC}-x-\mathrm{SO}_{3} \mathrm{H}$ materials was investigated (Table 1 ) by studying the effect of extracting excess furfuryl alcohol under vacuum. The composite after extraction could be loaded by the carbon compound to a maximum of $x=65 \%$ and when $x=51 \%$, the acid content was the highest, at $0.84 \mathrm{mmol} / \mathrm{g}$. By comparison, samples prepared without extraction were limited to a carbon loading of $52 \%$, leading to a maximum acid content of $0.71 \mathrm{mmol} / \mathrm{g}$, which was the same as that of a composite with vacuum extraction loaded with 44 wt\% carbon. As displayed in the XRD patterns (Fig. 1 (a), (8)), the excess introduction of furfuryl alcohol resulted in pore blockage in SBA-15, resulting in a CMK-3-type material with solid nanotubes after removing the silica template.

After the sequence of post-incorporation of $\mathrm{Al}^{3+}$ and furfuryl alcohol loading, the SC- $x$ materials retained a uniform 2D hexagonal mesopore array, as shown in the XRD patterns in Fig. 1(a). The peaks assigned to the [100], [110], and [200] diffractions of the 2D hexagonal structure $(p 6 \mathrm{~mm})$ of SBA-15 became gradually weaker in intensity with increasing carbon loading in the mesopores. This can be attributed to the diffraction inter-

Table 1

Comparison of the $\mathrm{CHO}$ loading and $-\mathrm{SO}_{3} \mathrm{H}$ acid density in $\mathrm{SC}-x-\mathrm{SO}_{3} \mathrm{H}$ with and without evacuation at $80^{\circ} \mathrm{C}$.

\begin{tabular}{lccccc}
\hline $\begin{array}{l}\text { Furfuryl alcohol/ } \\
\text { Al-SBA-15 }\end{array}$ & \multicolumn{2}{c}{$\mathrm{CHO}^{*}(\mathrm{wt} \%)$} & & \multicolumn{2}{c}{$\mathrm{H}^{+}(\mathrm{mmol} / \mathrm{g})$} \\
\cline { 2 - 3 } \cline { 5 - 6 } mass ratio & Evacuation & $\begin{array}{c}\text { Without } \\
\text { evacuation }\end{array}$ & & Evacuation & $\begin{array}{c}\text { Without } \\
\text { evacuation }\end{array}$ \\
\hline 0.5 & 15 & 26 & & 0.38 & 0.41 \\
0.75 & - & 34 & & - & 0.60 \\
1 & 26 & 40 & & 0.42 & 0.62 \\
1.5 & 34 & 48 & & 0.56 & 0.60 \\
2 & 41 & 52 & & 0.62 & 0.71 \\
2.5 & 44 & - & & 0.71 & - \\
3 & 51 & - & & 0.84 & - \\
4 & 61 & - & & 0.65 & - \\
5 & 65 & - & 0.48 & -
\end{tabular}

${ }^{*}$ Mass change by TG analysis in the $200-800^{\circ} \mathrm{C}$.
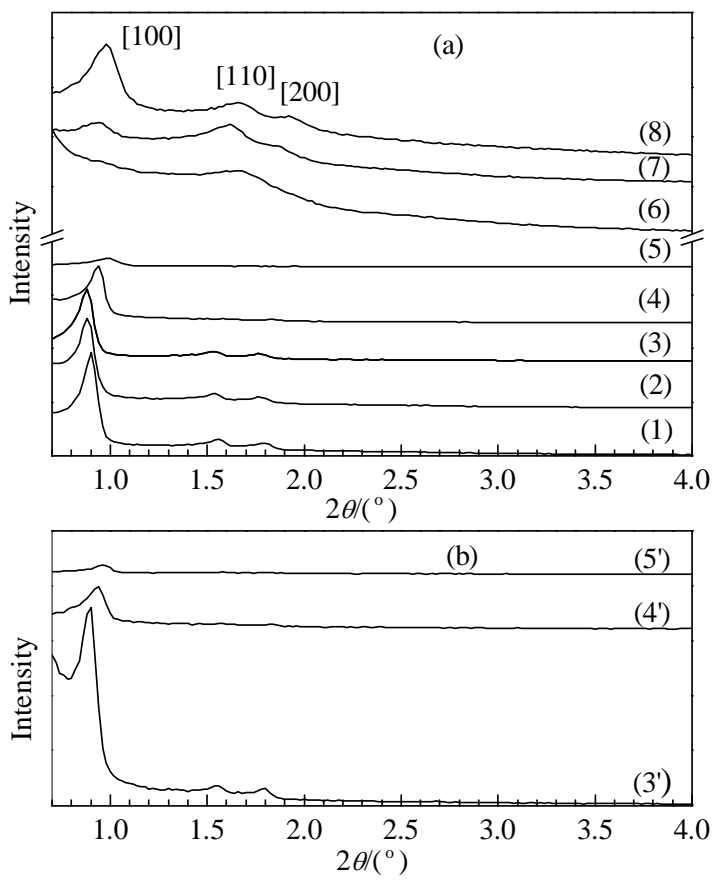

Fig. 1. Low-angle XRD patterns of samples before (a) and after (b) sulfonation. (1) SBA-15; (2) Al-SBA-15; (3) SC-26; (4) SC-34; (5) SC-44; (6) C-34; (7) C-44; (8) C-52; (3') SC-26- $\mathrm{SO}_{3} \mathrm{H}$; (4') $\mathrm{SC}-34-\mathrm{SO}_{3} \mathrm{H}$; (5') $\mathrm{SC}-44-\mathrm{SO}_{3} \mathrm{H}$.

ference from the carbon filling rather than a structural collapse (Fig. 1(a)). Moreover, the [100] peak broadening indicates a regional structure distortion of SBA-15 caused by excess carbon loading.

After the removal of silica, C- $x$ materials consisting of polycyclic benzene rings present a typical CMK-5-type mesoporous structure characteristic wherein diffraction peak [110] is more intensive than peak [100] [30]. This reveals that after the 550 ${ }^{\circ} \mathrm{C}$ calcination, furfuryl alcohol was converted into hollow nanotubes of the polycyclic benzene rings coating the silica wall, where the $\mathrm{Al}^{3+}$ was incorporated and catalyzed the polymerization. Greater carbon filling intensified peak [100], indicating that the wall of the nanotube was thickened and even transformed to the solid stick-like mesostructure of the CMK-3-type (Fig. 1(a)). The diffraction peaks were maintained after sulfonation (Fig. 1(b)), implying that the acid-inert silica support could protect the ordered structure of $\mathrm{SC}-x-\mathrm{SO}_{3} \mathrm{H}$.

The $\mathrm{N}_{2}$ adsorption-desorption isotherms and pore size distribution of SBA- 15 and SC- $x-\mathrm{SO}_{3} \mathrm{H}$ materials are demonstrated in Fig. 2(a) and (b), respectively, and their textural properties are listed in Table 2. With increasing carbon loading, the specific surface area of the composites decreased from $761 \mathrm{~cm}^{3} / \mathrm{g}$ in the SBA-15 support to $472 \mathrm{~cm}^{3} / \mathrm{g}$ in the SC-34-SO${ }_{3} \mathrm{H}$, and the pore size was simultaneously reduced from 8.1 to $3.6 \mathrm{~nm}$. However, SC- $x$-SO ${ }_{3} \mathrm{H}$ (when $x<44$ ) still had the classic type IV isotherm, indicating the presence of an ordered mesoporous structure (Table 2, Fig. 2(a) and 2(b)). The adsorption-desorption isotherms of SC-34-SO $\mathrm{S}_{3} \mathrm{H}$ began to disconnect, attributed to the typical structural features of organic mesoporous polymers that indicate a uniform coating of polycyclic benzene rings on the silica mesopore walls. At the same time, 

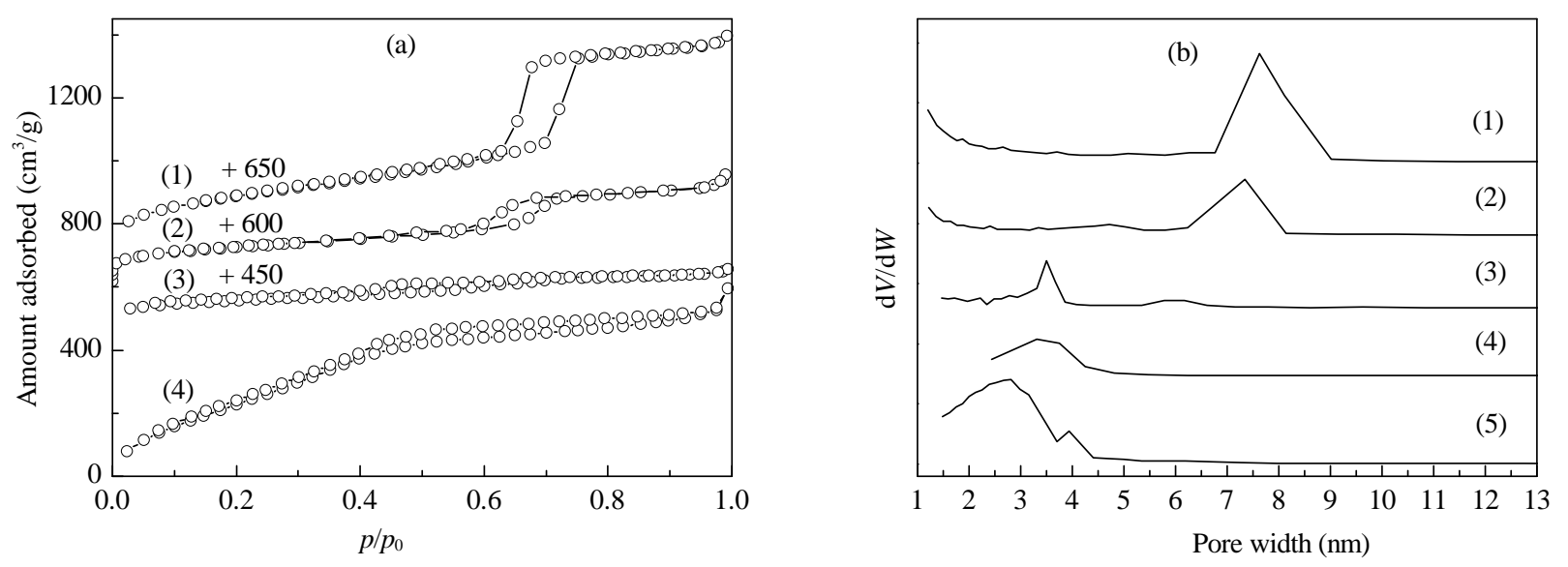

Fig. 2. (a) $\mathrm{N}_{2}$ adsorption-desorption of SBA-15 (1), SC-15- $\mathrm{SO}_{3} \mathrm{H}$ (2), $\mathrm{SC}-34-\mathrm{SO}_{3} \mathrm{H}$ (3), and C-44 (4), and (b) BJH pore diameter distribution of SBA-15 (1), $\mathrm{SC}-15-\mathrm{SO}_{3} \mathrm{H}(2), \mathrm{SC}-34-\mathrm{SO}_{3} \mathrm{H}(3), \mathrm{SC}-44-\mathrm{SO}_{3} \mathrm{H}(4)$, and C-44 (5).

the relative pressure of the hysteresis loop $p / p_{0}=0.65-0.70$ shifted to $p / p_{0}=0.5$, showing a reduced pore volume because of the increasing carbon coating layer. Furthermore, the layered benzene ring carbon generated $27 \%$ micropores in the total volume (Table 2), thus the hysteresis loop indicated a two-step desorption phenomenon (Fig. 2(a)). When the carbon loading was $x>50$, the isotherm was converted to type I and the specific surface area of SC-51- $\mathrm{SO}_{3} \mathrm{H}$ was reduced to 318 $\mathrm{cm}^{3} / \mathrm{g}$, with the micropore volume increasing to $48 \%$ of the total, which is higher than that of the $45 \% \mathrm{C} / \mathrm{CS}^{-S} \mathrm{H}_{3} \mathrm{H}(272$ $\mathrm{cm}^{3} / \mathrm{g}$ ) reported previously using sucrose as a carbon source [6], indicating the presence of a mesoporous structure.

After removing the silica template, C-34 and C- 44 appeared to have a type IV adsorption isotherm at $p / p_{0}=0.35$ and a steep capillary condensation, indicating a regular mesoporous structure. In addition, the existence of an unclosed hysteresis loop in the adsorption-desorption isotherms showed that the material consists of an organic framework as the mesoporous FDU-15, which is a polymerized phenolic resin [23]. Moreover, the C- $x$ samples have a superposed double-pore size distribution, similar to that of CMK-5, showing that the hollow carbon nanotubes formed in $\mathrm{C}-x$ have a typical hexagonal close-packed structure (Fig. 2(a), (4); Fig. 2(b), (5)). The double-pore size distribution on the right of the figure is attributed to the diameter of the poly-benzene ring carbon nanotube coating on the silica wall, while on the left, the broader distribution is caused

Table 2

Textural properties of SC- $x-\mathrm{SO}_{3} \mathrm{H}$ and $\mathrm{C}-x$ samples.

\begin{tabular}{|c|c|c|c|c|}
\hline Sample & $\begin{array}{c}A_{\mathrm{BET}} / \\
\left(\mathrm{m}^{2} / \mathrm{g}\right)\end{array}$ & $\begin{array}{l}\text { Pore volume } \\
\left(\mathrm{cm}^{3} / \mathrm{g}\right)\end{array}$ & $V_{\text {micro }}{ }^{\mathrm{a}} / \%$ & $d^{\mathrm{b}} / \mathrm{nm}$ \\
\hline$\overline{\text { SBA-15 }}$ & 761 & 1.17 & 6 & 8.1 \\
\hline $\mathrm{SC}-34-\mathrm{SO}_{3} \mathrm{H}$ & 472 & 0.37 & 27 & 3.6 \\
\hline $\mathrm{SC}-44-\mathrm{SO}_{3} \mathrm{H}$ & 442 & 0.27 & 41 & 3.4 \\
\hline $\mathrm{SC}-51-\mathrm{SO}_{3} \mathrm{H}$ & 318 & 0.20 & 48 & $<2.0$ \\
\hline$C-34$ & 1420 & 1.15 & - & $4.2^{\mathrm{c}}\left(1.9^{\mathrm{d}}\right)$ \\
\hline$C-44$ & 1112 & 0.89 & - & $3.9(2.1)$ \\
\hline
\end{tabular}

by the tube gap, which depends on the thickness of the SBA-15 pore wall as well as wall-attached species such as Al [30]. The thickness of the carbon nanotube wall was increased with greater furfuryl alcohol loading (Table 2, C-34 and C-44), and the presence of hollow tubes greatly promotes the transport and diffusion of macromolecules within the pores.

The SEM images provide further evidence that the $\mathrm{C}-44-\mathrm{SO}_{3} \mathrm{H}$ material has a similar mesoporous structure to that of CMK-5. It has a 2D hexagonally close-packed tube arrangement, with a wall thickness of approximately $2 \mathrm{~nm}$ and an irregular tube gap of approximately $4 \mathrm{~nm}$ (Fig. 3). This structure remains after sulfonation, further indicating the high stability of its mechanical, physical, and chemical properties.

Incorporated sulfonic groups can be determined by FT-IR spectra, as shown in Fig. 4(a). A broad absorption peak in the region $1000-1300 \mathrm{~cm}^{-1}$ observed on $\mathrm{SC}-34-\mathrm{SO}_{3} \mathrm{H}$ sample is attributed to the $\mathrm{Si}-\mathrm{O}$ stretching vibration, while a sharp peak appears at $1032 \mathrm{~cm}^{-1}$ after removing the silica, assigned to the symmetric $\mathrm{S}=\mathrm{O}$ stretching, indicating that the $-\mathrm{SO}_{3} \mathrm{H}$ groups

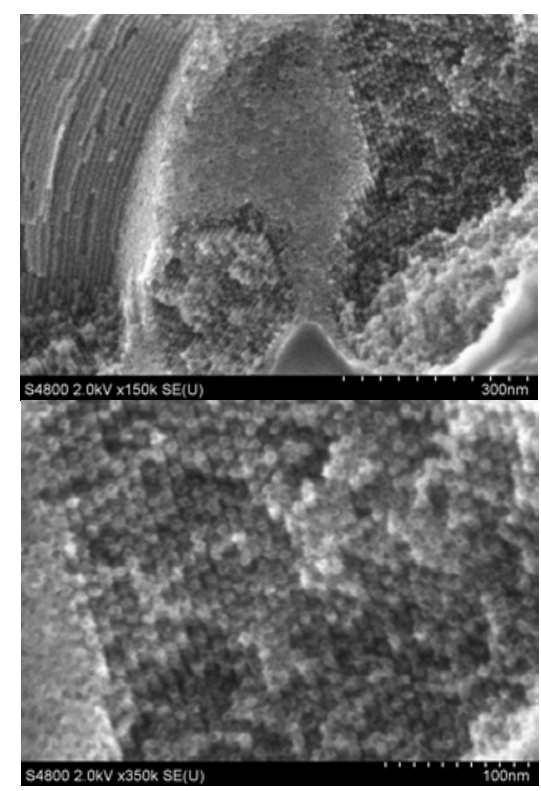

Fig. 3. SEM images of $\mathrm{C}-44-\mathrm{SO}_{3} \mathrm{H}$ samples. 

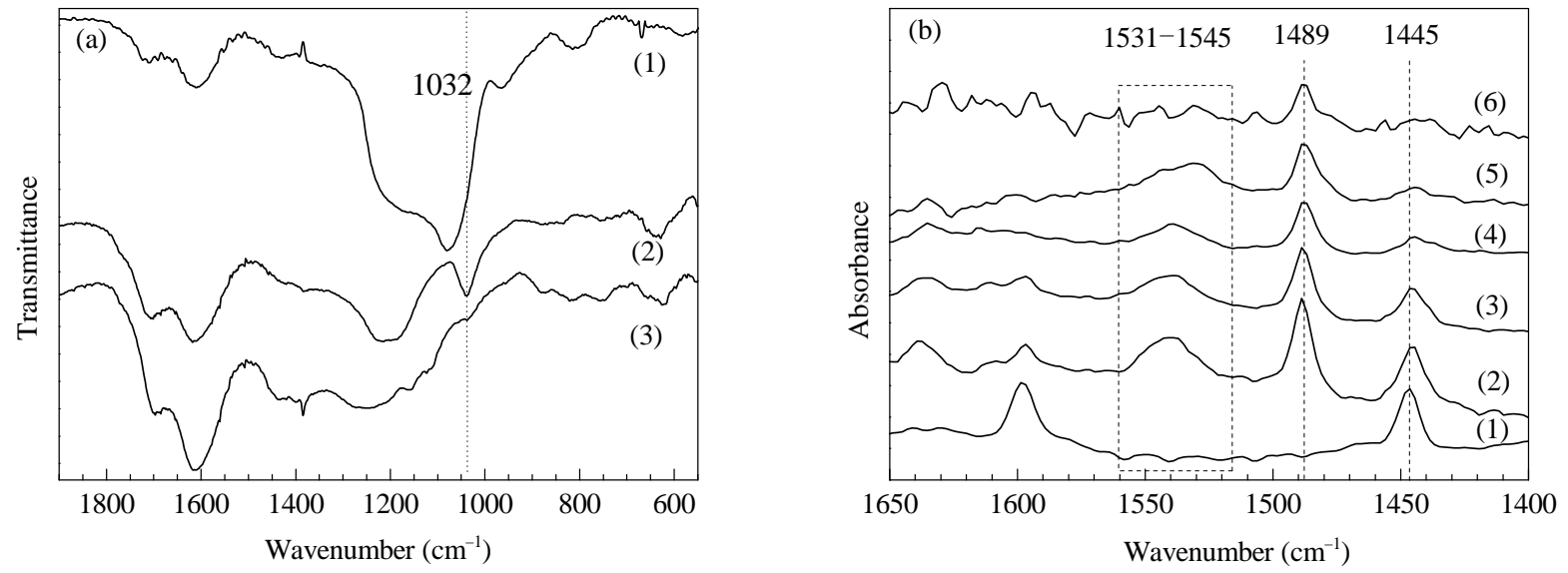

Fig. 4. (a) FT-IR spectra of SC-34- $\mathrm{SO}_{3} \mathrm{H}(1), \mathrm{C}-34-\mathrm{SO}_{3} \mathrm{H}(2)$, and $\mathrm{C}-34$ (3), and (b) FT-IR spectra of adsorbed pyridine after desorption at $150{ }^{\circ} \mathrm{C}$ for SBA-15 (1), SC-15- $\mathrm{SO}_{3} \mathrm{H}(2), \mathrm{SC}-26-\mathrm{SO}_{3} \mathrm{H}(3), \mathrm{SC}-34-\mathrm{SO}_{3} \mathrm{H}(4), \mathrm{SC}-44-\mathrm{SO}_{3} \mathrm{H}(5)$, and SC-51- $\mathrm{SO}_{3} \mathrm{H}(6)$.

have been successfully grafted onto the polycyclic benzene ring. Compared with C-34, a significant absorption band can be observed at about $1210 \mathrm{~cm}^{-1}$ for $\mathrm{C}-34-\mathrm{SO}_{3} \mathrm{H}$, which is attributed to the $-\mathrm{COOH}$ group in the mode of $\mathrm{C}=0$ stretching vibration, revealing that sulfonation also catalyzed the conversion of organic carbon compounds into carboxylic acid groups [24,26].

FT-IR spectrum of adsorbed pyridine was applied to verify the type and density of acid sites [31]. Sulfonated samples were dehydrated at $150{ }^{\circ} \mathrm{C}$ under vacuum, then cooled to $110{ }^{\circ} \mathrm{C}$, adsorbing pyridine, finally followed by desorption at $150{ }^{\circ} \mathrm{C}$ to avoid physical adsorption [6]. Fig. 4(b) shows the FT-IR spectra of SC- $x$ - $\mathrm{SO}_{3} \mathrm{H}$ materials after pyridine adsorption with a series of absorption bands in the range 1531-1545, 1489, and 1445 $\mathrm{cm}^{-1}$ caused by pyridine ring stretching. These correspond to the combination of pyridine with the Brönst acid sites, the Brönst acid sites and/or Lewis acid sites, and the Lewis acid sites and/or Si-OH, respectively. Increasing the furfuryl alcohol loading did not affect the peak intensity in the range of 1531-1545 $\mathrm{cm}^{-1}$. When the loading of alcohol was further increased, the numbers of acid sites were sharply reduced for the SC-51-SO ${ }_{3} \mathrm{H}$ sample. Two reasons are proposed: one is that the hydrogen bonding generated by increasing sulfonic acid groups stops the combination of pyridine and B acid sites; the other is that the accessibility of acid sites was blocked by thickening of the carbon layer (pore size less than $2.0 \mathrm{~nm}$, Table 2).

\subsection{Catalytic reaction}

Because acid content and specific surface area are the two main factors that influence activity, the solid acid catalysts prepared with furfuryl alcohol and sucrose as carbon source, respectively, were compared for the acetalization of cyclopentanone and ethylene glycol (Fig. 5). For both materials, when the carbon precursor loading was less than 35\%, the amount of sulfonic acid increased with carbon loading. The maximum acid value for the composite synthesized with sucrose was 0.70 $\mathrm{mmol} / \mathrm{g}$ when $x=35$, while for the furfuryl alcohol composite, it was up to $0.84 \mathrm{mmol} / \mathrm{g}$ at $x=50$ carbon loading. Note that the latter, with $50 \%$ carbon, had nearly $100 \mathrm{~m}^{2} / \mathrm{g}$ higher surface area than the former, thus the solid acid synthesized using furfuryl alcohol catalytically yielded a maximum of $82 \mathrm{~mol} \%$ acetal compared with $63 \mathrm{~mol} \%$ by sucrose composites. According to a previous report [6], the composite using sucrose as carbon precursor easily caused SBA-15 pore blockage with increasing carbon, which sharply decreased the surface area and pore volume, and its maximum acid value was reached at $x=35$. In contrast, the carbon layer derived from furfuryl alcohol was a uniform coating on the silica wall of SBA-15, and this improved the substitution of acid groups, leading to a higher acid intensity. Moreover, the stable mesostructure with hollow nanotubes can provide a larger reaction space that not only increases the accessible acid sites but also enhances the transport and diffu-

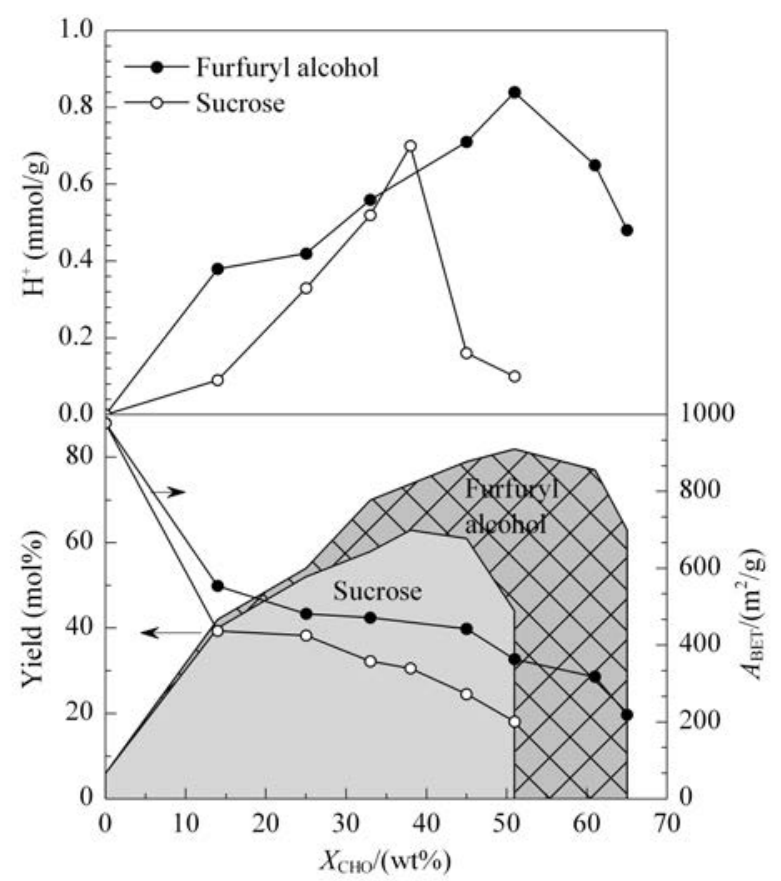

Fig. 5. Acetalization of cyclopentanone on the $\mathrm{SC}-x-\mathrm{SO}_{3} \mathrm{H}$ and $x \% \mathrm{C} / \mathrm{CS}_{-}-\mathrm{SO}_{3} \mathrm{H}$, respectively. Reaction conditions: cyclopentanone 40 mmol, ethylene glycol $48 \mathrm{mmol}$, cyclohexane $5 \mathrm{ml}$, catalyst $40 \mathrm{mg}, 90^{\circ} \mathrm{C}$, $1 \mathrm{~h}$. 
sion of the substrate and/or product.

Because of the considerable active amount of acid and large reaction space, $\mathrm{SC}-34-\mathrm{SO}_{3} \mathrm{H}$ was tested to further investigate the catalytic activity of the solid acid $\mathrm{SC}-x-\mathrm{SO}_{3} \mathrm{H}$ on acetalization of large molecules. The acetalization of iso-valeraldehyde, iso-butyraldehyde, benzaldehyde, and cyclohexanone with ethylene glycol all showed $>90 \%$ yield, indicating the high catalytic activity of SC-34- $\mathrm{SO}_{3} \mathrm{H}$ (Table 3, entries 1, 3, 5 and 7), while for 1,4-butanediol, the yield is slightly reduced by about $5 \%$ (Table 3, entries 2, 4, 6, and 8). In addition, when using 3 -pentanone or benzophenone as substrates, the yield continued to decrease because of pore size restriction and also the steric effect of the large molecules, which have branched chains with a $\mathrm{C}=\mathrm{O}$ functional group in the middle. Clearly, the presence of such hidden or diffusion-limited sulfonic acid groups resulted in a reduced yield of the product (Table 3, entries 9-12). The reaction of benzaldehyde and ethylene glycol could yield $91 \%$, indicating that $\mathrm{SC}-34-\mathrm{SO}_{3} \mathrm{H}$ has a high reactivity towards molecules as large as benzaldehyde (Table 3, entry 5), while replacing this with benzophenone yielded $56 \%$ acetal after $5 \mathrm{~h}$ (Table 3 , entry 11). Compared with benzaldehyde, benzophenone has twice the rigid size, thus only half the amount can be held in the same reaction space within the catalyst, probably leading to nearly half the yield. Similarly, the reaction of benzophenone and 1,4-butanediol yielded $25 \%$, which is exactly half of the

Table 3

Acetalization of various aldehydes or ketones on the $\mathrm{SC}-34-\mathrm{SO}_{3} \mathrm{H}$ catalyst.

Entry

Reaction conditions: aldehyde or ketone $40 \mathrm{mmol}$, alcohol $48 \mathrm{mmol}$, cyclohexane $5 \mathrm{ml}$, catalyst $40 \mathrm{mg}, 90^{\circ} \mathrm{C}, 1 \mathrm{~h}(* 5 \mathrm{~h})$. yield from the reaction using ethylene glycol as the alcohol (Table 3, entries 11 and 12) because of the difference between the alcohol sizes. This further supports the existence of considerable amounts of acid sites and a facile accessibility, which enable superior reactivity towards acetalization.

After the reaction of cyclohexanone and ethylene glycol, SC-34- $\mathrm{SO}_{3} \mathrm{H}$ solid acid catalyst was recovered by filtration, washed thoroughly with cyclohexane and dried. The catalyst was then tested for reuse six times, finally obtaining a yield reduction of about $5 \%$. Note that the poly-benzene ring layer formed under the $\mathrm{Al}^{3+}$ catalyzed thermal polymerization and vacuum extraction was firmly attached onto the silica wall, and the composite demonstrated a high stability during reuse.

\section{Conclusions}

Furfuryl alcohol loaded SBA-15 was thermally polymerized at $550{ }^{\circ} \mathrm{C}$ into the polycyclic benzene ring carbon layer coated on the silica wall as regular hollow carbon nanotubes. After sulfonation, a functionalized carbon-silica solid acid was obtained with variable sulfonic acid sites. The catalyst shows excellent activity towards the acid-catalyzed acetalization of bulky aldehyde or ketone molecules with alcohols and is expected to be widely applicable because of its easy preparation and post-handling, compared with composites using sucrose as a carbon precursor.

\section{References}

[1] Pillai S K, Gheevarghese O, Sugunan S. Appl Catal A, 2009, 353: 130

[2] Katada N, Iseki Y, Shichi A, Fujita N, Ishino I, Osaki K, Torikai T, Niwa M. Appl Catal A, 2008, 349: 55

[3] Shimizu K, Niimi K, Satsuma A. Appl Catal A, 2008, 349: 1

[4] Atia H, Armbruster U, Martin A. J Catal, 2008, 258: 71

[5] Fang L, Xing R, Wu H H, Li X H, Liu Y M, Wu P. Sci China Chem, 2010, 53: 1481

[6] Fang L, Zhang K, Li X H, Wu H H, Wu P. Chin J Catal (方林, 张坤, 李 晓红, 吴海虹, 吴鹏. 催化学报), 2012, 33: 114

[7] Harmer M A, Sun Q. Appl Catal A, 2001, 221: 45

[8] Saha M S, Nishiki Y, Furuta T, Denggerile A, Ohsaka T. Tetrahedron Lett, 2003, 44: 5535

[9] Serio M D, Tesser R, Dimiccoli M, Cammarota F, Nastasi M, Santacesaria E.J Mol Catal A, 2005, 239: 111

[10] Liu K S. J Am Oil Chem Soc, 1994, 71: 1179

[11] Wang X G, Chen C C, Chen S Y, Mou Y, Cheng S. Appl Catal A, 2005, 281: 47

[12] Ratnama K J, Reddy R S, Sekhar N S, Kantama M L, Deshpande A, Figueras F. Appl Catal A, 2008, 348: 26

[13] Zareyee D, Karimi B. Tetrahedron Lett, 2007, 48: 1277

[14] Das B, Kanth B S, Reddy K R, Kumar A S.J Heterocyclic Chem, 2008, 45: 1499

[15] Barrault J, Jerome F. Eur J Lipid Sci Technol, 2008, 110: 825

[16] Saikia L, Satyarthi J K, Srinivas D, Ratnasamy P. J Catal, 2007, 252: 148

[17] Dias A S, Pillinger M, Valente A A.J Catal, 2005, 229: 414

[18] Shimizu K, Hayashi E, Hatamachi T, Kodama T, Higuchi T, Satsuma A, Kitayama Y. J Catal, 2005, 231: 131

[19] Landge S M, Berryman M, Török B. Tetrahedron Lett, 2008, 49: 4505

[20] Balaraju M, Rekha V, Prasad P S S, Devi B L A P, Prasad R B N, 


\title{
Graphical Abstract
}

Chin. J. Catal., 2013, 34: 932-941 doi: 10.1016/S1872-2067(12)60591-9

\section{Carbon-coated mesoporous silica functionalized with sulfonic acid groups and its application to acetalization}

FANG Lin, ZHANG Kun*, CHEN Lu, WU Peng * East China Normal University

Polycyclic carbon-coated SBA-15 serves as a stable solid acid catalyst after sulfonation, and is efficient during acetalization of aldehydes/ketones with alcohol because of its high surface area and abundant Brönsted acid sites.

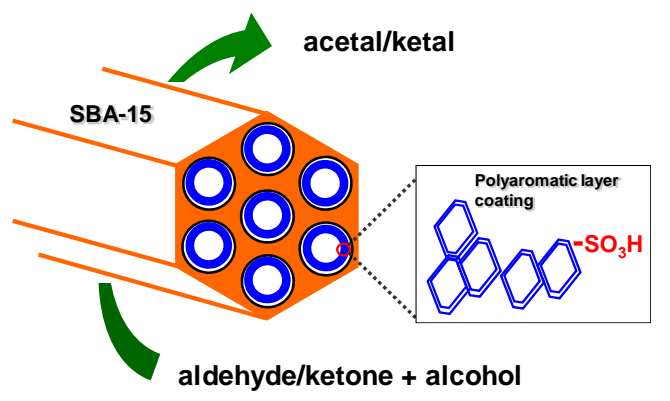

Lingaiah N. Appl Catal A, 2009, 354: 82

[21] Li D M, Shi F, Peng J J, Guo Sh, Deng Y Q. J Org Chem, 2004, 69: 3582

[22] Shimizu K, Hayashi E, Hatamachi T, Kodama T, Higuchi T, Satsuma A, Kitayama Y.J Catal, 2005, 231: 131

[23] Xing R, Liu N, Liu Y M, Wu H H, Jiang Y W, Chen L, He M Y, Wu P. Adv Funct Mater, 2007, 17: 2455

[24] Toda M, Takagaki A, Okamura M, Kondo J N, Hayashi S, Domen K, Hara M. Nature, 2005, 438: 178

[25] Xing R, Liu Y M, Wang Y, Chen L, Wu H H, Jiang Y W, He M Y, Wu P. Microporous Mesoporous Mater, 2007, 105: 41
[26] Nakajima K, Okamura M, Kondo J N, Domen K, Tatsumi T, Hayashi S, Hara M. Chem Mater, 2009, 21: 186

[27] Augustine J K, Bombrun A, Sauer W H B, Vijaykumar P. Tetrahedron Lett, 2012, 53: 5030

[28] Sato S, Sagara K, Furuta H, Nozaki F. J Mol Catal A, 1996, 114: 209

[29] Shao L J, Xing G Y, He L Y, Chen J, Xie H Q Liang X Zh, Qi Ch Z. Appl Catal A, 2012, 443-444: 133

[30] Darmstadt H, Roy C, Kaliaguine S, Kim T-W, Ryoo R. Chem Mater, 2003, 15: 3300

[31] Wang Y, Liu Y M, Li X H, Wu H H, He M Y, Wu P. J Catal, 2009, 266: 258

\section{碳-硅复合介孔磺酸催化剂的制备及其在缩醛(酮)反应中的应用}

\author{
方林, 张 坤, 陈 露, 吴 鹏* \\ 华东师范大学化学系上海市绿色化学与化工过程绿色化重点实验室, 上海200062
}

摘要: 采用浸渍法将糠醇负载在铝改性的SBA-15介孔孔道中, 经 $550^{\circ} \mathrm{C}$ 不完全碳化制备了结构规整、含多苯环的中空管状硅碳复 合介孔材料. 结果表明, 通过温和磺酸化作用可使磺酸基团成功取代在多苯环上, 其酸量随着多苯环涂层厚度变化在 0.38 0.84 $\mathrm{mmol} / \mathrm{g}$ 范围内可控调变. 相比于蔗糖作为糖源的复合固体酸, 所制碳多苯环-硅酸催化剂具有中空碳纳米管堆积的类似CMK-5介 孔结构, 以及较大的反应空间、稳定的机械性能、较高的比表面和大量可以接触的质子酸中心, 因而在大分子缩醛(酮)反应中表 现了良好的催化性能.

关键词: 固体酸; 介孔碳; 磺酸根; 缩醛(酮)反应

收稿日期: 2012-12-29. 接受日期: 2013-03-20. 出版日期: 2013-05-20.

*通讯联系人. 电话/传真: (021)62232292; 电子信箱：pwu@chem.ecnu.edu.cn

\#通讯联系人. 电话/传真: (021)62232753; 电子信箱: kzhang@chem.ecnu.edu.cn

基金来源：国家自然科学基金(220925310，21003050, U1162102); 国家科技支撑计划(2012BAE05B02); 上海市重点学科建设 (B409).

本文的英文电子版由Elsevier出版社在ScienceDirect上出版(http://www.sciencedirect.com/science/journal/18722067).

\section{1. 前言}

固体酸催化剂具有易重复使用、使用寿命长、环境 污染小等优点, 因而被广泛应用于石油炼制和精细化工 等领域. 金属氧化物 ${ }^{[1,2]}$ 、杂多酸 ${ }^{[3,4]}$ 、磺酸功能化多孔材 料 ${ }^{[5,6]}$ 和酸性离子交换树脂 ${ }^{[7,8]}$ 等固体酸可以替代硫酸、
脂肪酸盐 ${ }^{[9]}$ 和有机磺酸 ${ }^{[10]}$ 等均相酸, 用于催化多种反应 中,如贝克曼重排 ${ }^{[11,12]}$ 、烷基化 ${ }^{[13]}$ 、酯化及水解 ${ }^{[5,6]}$ 、酰 化 $^{[14]}$ 、醚化 ${ }^{[15]}$ 、环氧化物及烯烃的加成与醇类的脱 水 ${ }^{[16,17]}$ 、缩合反应 ${ }^{[18,19]}$ 和加氢重整 ${ }^{[20]}$ 等.

最近, 为使催化剂能够有效循环使用且不污染环境, 含有磺酸基团的非均相酸如离子液体 ${ }^{[21]}$ 、磺酸修饰的有 
机无机杂化材料 ${ }^{[22,23]}$ 以及糖碳磺酸材料 ${ }^{[24]}$ 等得到广泛 研究. Xing 等 ${ }^{[25]}$ 以SBA-15为硬模板, 填充蔗糖并进行不 完全炭化制得富含碳多苯环的类CMK-3介孔碳材料, 同 时采用可控磺化法将磺酸基团嫁接到多苯环骨架, 使其 成为一种新型介孔固体酸. 相比于Nakajima等 ${ }^{[26]}$ 制得的 糖碳磺酸较低 $\left(2 \mathrm{~m}^{2} / \mathrm{g}\right)$ 的比表面积, CMK-3-SO ${ }_{3} \mathrm{H}$ 比表面 积接近 $1000 \mathrm{~m}^{2} / \mathrm{g}$, 酸量约 $1.0 \mathrm{mmol} / \mathrm{g}$, 因而在液相贝克曼 重排反应中表现出优异的催化活性. 然而 CMK-3- $\mathrm{SO}_{3} \mathrm{H}$ 在实际应用中, 尤其是在磺化过程中, 碳骨架结构很容 易因为深度碳化而坍塌. 为了提高这种材料的可操作性 和稳定性, Fang 等 ${ }^{[6]}$ 调变碳多苯环在SBA-15介孔孔道中 的负载量, 然后进行简单的磺化作用, 得到了兼有大比表 面积和丰富酸量的碳多苯环-硅复合固体酸材料, 是催化 酯化及酯交换合成生物柴油的优良催化剂.

尽管碳多苯环-硅复合固体酸材料中, 碳多苯环增 加, 可提供更多苯环被磺酸基团取代, 但由于蔗糖的随 机填充导致碳多苯环在SBA-15介孔孔道内无序堆积, 易 造成孔道堵塞, 使得样品比表面积急剧下降, 难以体现多 孔材料的反应空间优势. 因此, 如何使样品维持高的酸 量, 且具有宽敞规整的反应空间成为开发此类材料的挑 战之一, 另一方面, 在众多的酸催化反应中, 缩醛化反应 通常用于保护羰基醛和酮类; 同时, 缩醛也是合成类固 醇、药品、油漆和香水等产品对映体化合物的主要原料, 因而具有广泛的应用前景. 该反应通常在均相酸催化条 件下进行具有较高的收率和选择性 ${ }^{[27]}$. 然而杂多酸 ${ }^{[21]}$ 和离子液体等非均相催化剂的酸性较弱、热稳定性较低, 因而需要在低温反应较长时间产物收率才可达到 $90 \%$ 以上的收率 ${ }^{[28]}$; 而对于酸性高反应空间小的固体酸, 如 磺酸功能化的纳米硅纤维 ${ }^{[29]}$, 则需在 $150{ }^{\circ} \mathrm{C}$ 高温条件下 才能得到较高收率.

本文利用由糠醇制备CMK-5的方法 ${ }^{[30]}$, 在Al修饰的 SBA-15载体上负载糠醇, 孔道内壁富集Al酸性位以及较 低温度下的真空抽取, 使糠醇在不完全焙烧条件下在孔 壁上热聚形成规整的碳多苯环层, 然后对其进行磺酸功 能化, 最终得到碳多苯环-硅复合介孔固体酸, 并用于缩 醛(酮)反应中.

\section{2. 实验部分}

\section{1. 催化剂的制备}

以正硅酸乙酯 (TEOS, Sigma-Aldrich) 为前驱体, $\mathrm{P} 123$ 三嵌段共聚物 $\left(M_{\mathrm{w}} \approx 5800\right.$, Sigma-Aldrich)为模板剂, 在酸性水溶液中合成 SBA-15 $5^{[6]}$. 将 $1 \mathrm{~g}$ 焙烧过的
SBA-1 $5^{[31]}$ 浸渍于含有 $0.12 \mathrm{~g} \mathrm{AlCl}_{3}$ 的 $25 \mathrm{ml}$ 无水乙醇(国 药集团) 溶液中 (投料时摩尔比 $\mathrm{Si} / \mathrm{Al}=20$ ), 于室温搅拌 14 $\mathrm{h}$, 混和物经抽滤并用无水乙醇洗涤, 在 $80^{\circ} \mathrm{C}$ 烘干, $550{ }^{\circ} \mathrm{C}$ 空气中焙烧 $6 \mathrm{~h}$, 即得 $\mathrm{Al}-\mathrm{SBA}-15$ (摩尔比 $\mathrm{Si} / \mathrm{Al}=$ 19.2).

在1 g该铝硅材料上负载 $0.5 \sim 5 \mathrm{~g}$ 糠醇 $>98.0 \%$, 国药 集团), 室温下手动搅拌直至均匀; 然后在 $80^{\circ} \mathrm{C}$ 下热聚 1 $\mathrm{h}$ 将其移至真空系统, 在 $80^{\circ} \mathrm{C}$ 下抽空 $1 \mathrm{~h}$ 以去除多余糠醇 液体. 最后在 $\mathrm{N}_{2}$ 保护下, 升至 $550{ }^{\circ} \mathrm{C}$ 不完全炭化 $6 \mathrm{~h}$, 得 到一系列碳硅复合材料的样品 SC $-x$, 其中 $x$ 为碳化物的 质量含量(\%). 将 $\mathrm{SC}-x$ 置于密闭容器上方, 下方预放固/ 液比为 $1 / 20(\mathrm{~g} / \mathrm{ml})$ 的发烟硫酸 $\left(50 \% \mathrm{SO}_{3} / \mathrm{H}_{2} \mathrm{SO}_{4}\right.$, 国药集 团), 在 $80{ }^{\circ} \mathrm{C}$ 静置 $12 \mathrm{~h}$. 取出, 固体产物用 $80^{\circ} \mathrm{C}$ 以上的热 水反复洗涤, 用 $\mathrm{BaCl}_{2}(\geqslant 99.0 \%$, 国药集团)检测滤液无 $\mathrm{SO}_{4}{ }^{2-}$; 再经干燥后得到 $\mathrm{SC}-x-\mathrm{SO}_{3} \mathrm{H}$.

$\mathrm{SC}-x$ 及 SC- $x-\mathrm{SO}_{3} \mathrm{H}$ 在固/液比为 $1 / 20(\mathrm{~g} / \mathrm{ml}), 15 \%$ 的 $\mathrm{HF}(\geqslant 40 \%$, 国药集团)水溶液中室温搅拌过夜, 过滤, 去 离子水洗涤, 烘干, 可得到纯碳材料 $\mathrm{C}-x$ 或 $\mathrm{C}-x-\mathrm{SO}_{3} \mathrm{H}$. 对 比催化剂庶糖-硅复合固体酸的制备方法见文献[6].

\section{2. 催化剂的表征}

$\mathrm{X}$ 射线粉末衍射 (XRD) 测试在 Bruke 公司 D8 ADVANCE型X射线粉末衍射仪上进行, $\mathrm{Cu}-K_{\alpha}$ 为射线源 $(\lambda=0.15406 \mathrm{~nm})$. 样品的比表面积和孔径分析在 Quantachrome公司Autosorb3-B型自动物理吸附仪上进 行, 吸附温度为 $-196^{\circ} \mathrm{C}$. 吸附前, 样品在 $120^{\circ} \mathrm{C}$ 的真空 条件下处理 6 h. 采用日本日立公司Hitachi S-4800型冷 场高分辨率发射扫描电子显微镜(SEM)对催化剂粒径和 表面形貌进行分析. 红外光谱(FT-IR)在美国Nicolet公 司Nexus 670型傅里叶变换红外光谱仪上测试, $\mathrm{KBr}$ 压片. 样品先在 $150^{\circ} \mathrm{C}$ 真空脱水处理 $5 \mathrm{~h}$, 再在 $110^{\circ} \mathrm{C}$ 吸附吡啶 $0.5 \mathrm{~h}$; 在 $150^{\circ} \mathrm{C}$ 下脱去物理吸附吡啶后测定其FT-IR谱. 利用 Mettler-Toledo公司 TG/DTA 851e型热分析仪记录 样品的热失重(TG)和差热曲线(DTA).

在 $100 \mathrm{ml}$ 小烧杯中加入 $60 \mathrm{ml} \mathrm{NaCl}$ 饱和溶液, 以及 待标定样品约 $(0.15 \pm 0.01) \mathrm{g}$, 于室温搅拌 $12 \mathrm{~h}$, 抽滤. 以 酚酞为指示剂, 用已用邻苯二甲酸氢钾标定的 $\mathrm{NaOH}$ 溶 液滴定滤液, 得到样品的酸值.

\section{3. 催化反应}

醛(酮)与乙二醇的缩合反应在 $100 \mathrm{ml}$ 三颈瓶中进行, 加入 $0.04 \mathrm{~mol}$ 醛(酮), $0.048 \mathrm{~mol}$ 醇(环己酮, 环戊酮, 3-戊 酮, 乙二醇和1,4-丁二醇来自国药集团; 苯甲醛, 异戊醛 和二苯甲酮来自 $\mathrm{TCI}$ ), $40 \mathrm{mg}$ 催化剂, 以及 $5 \mathrm{ml}$ 环己烷 $(\geqslant$ 
99.5\%, 国药集团). 三颈瓶接上冷凝管和分水器, 在 $90{ }^{\circ} \mathrm{C}$ 下加热搅拌回流 $1 \mathrm{~h}$, 使反应产生的水与带水剂环 己烷共沸蒸出, 反应结束后取样分析. 反应产物采用美 国Agilent 6890/5973N型气相色谱-质谱联用(GC-MS)仪 进行定性分析. 定量分析在日本岛津14-B型气相色谱仪 上进行, DB-WAX毛细管柱 $(\phi 0.25 \mathrm{~mm} \times 30 \mathrm{~m})$.

\section{3. 结果与讨论}

\section{1. 材料结构及化学性质的表征结果}

表1给出了 $\mathrm{SC}-\mathrm{x}-\mathrm{SO}_{3} \mathrm{H}$ 材料碳多苯环负载量、磺化酸 量, 以及制备过程中是否受到 $80{ }^{\circ} \mathrm{C}$ 真空抽取多余糠醇 步骤的影响. 由表可见, 碳多苯环负载量可达 $65 \%$; 当 为 $51 \%$ 时, 磺化酸量可达 $0.84 \mathrm{mmol} / \mathrm{g}$. 若不真空抽除, 碳 多苯环负载量和磺化酸量最高为 $52 \%$ 和 $0.71 \mathrm{mmol} / \mathrm{g}$, 后 者与抽真空时 $x=44$ 的相同. 另一方面, 糠醇过多且不抽 空处理, 容易导致负载不均匀和孔道堵塞现象. 图1(a) 的XRD谱表明, 该材料在焙烧、脱除硅模板之后形成了 类似CMK-3实心棍状介孔结构.

图1为各样品的XRD谱. 可以看出, 继骨架后补 $\mathrm{Al}$ 以及随后糠醇的负载, 复合材料 SC $-x$ 依然保持了二维六 方孔道结构. 碳多苯环负载量的增加使得母体介孔硅的 衍射峰强度逐渐减弱, 其中 [100]峰宽化, 说明糠醇的过 量负载可导致介孔结构畸化. 去除硅基模板后, 多苯环 材料C- $x$ 出现类似于 CMK- 5 的典型介孔空管结构特征衍 射峰, 即 [110]峰强度强于 [100]峰 ${ }^{[30]}$. 说明在 $550{ }^{\circ} \mathrm{C}$ 焙烧 下, 糠醇受介孔孔壁上Al酸位作用而转化的碳多苯环, 可均匀地负载于孔壁上, 形成类似于中空碳纳米管的介 孔结构. 另外, 样品中碳多苯环含量越高, 其[100]峰强 度越高, 说明管壁增厚, 中空管结构向实心棍状转化 (见 样品C-34和C-44). 经磺化反应后, 所得样品的XRD衍射 峰未发生明显变化, 说明稳定的硅基结构可保护 $\mathrm{SC}-x-\mathrm{SO}_{3} \mathrm{H}$ 在磺化作用下的有序度(见图1(b)).

图2为各SC- $x$ 样品的氮气吸附-脱附等温线及孔径 分布图, 相应的结构性质列于表2. 可以看出, 随着碳多 苯环在样品中负载量的上升, 其比表面积由SBA-15的 $761 \mathrm{~cm}^{3} / \mathrm{g}$ 降至SC-34- $\mathrm{SO}_{3} \mathrm{H}$ 的 $472 \mathrm{~cm}^{3} / \mathrm{g}$, 孔径由 $8.1 \mathrm{~nm}$ 变 为 $3.6 \mathrm{~nm}$, 孔体积减小了 $2 / 3$, 但是 $\mathrm{SC}-x-\mathrm{SO}_{3} \mathrm{H}(x<44)$ 样 品的等温线为典型的 $\mathrm{V}$ 型, 表明其存在高度有序介孔结 构. SC-34- $\mathrm{SO}_{3} \mathrm{H}$ 样品的等温线开始出现滞后环无法闭 合的现象, 归属于有机介孔聚合物的典型结构特征, 与 蔗糖填充物的无序堆积状态明显不同 ${ }^{[6]}$. 这进一步证明 该材料中多苯环聚合物以均匀涂层的形式负载于介孔
孔壁. 同时, 滞后环由 $p / p_{0}=0.65 \sim 0.70$ 向低比压区 $p / p_{0}=$ 0.5 移动, 说明由于多苯环聚合物的填充孔径, 尺寸逐渐 减小. 另外, 由于碳多苯环的层叠产生了相当数量的微 孔(占据总体积的 $27 \%$ ), 滞后环呈现双台阶吸脱附现象. 当 $x>50$ 时, 所得样品的等温线由 IV 型变为 $\mathrm{I}$ 型, 其中 $\mathrm{SC}-51-\mathrm{SO}_{3} \mathrm{H}$ 的比表面积降至 $318 \mathrm{~cm}^{3} / \mathrm{g}$, 微孔体积增至 $48 \%$, 前者远远高于蔗糖-硅复合材料 $45 \% \mathrm{C} / \mathrm{CS}-\mathrm{SO}_{3} \mathrm{H}(x$ $=44)$ 的 $272 \mathrm{~cm}^{3} / \mathrm{g}^{[6]}$, 表明有大量介孔存在.

去除SC-34和SC-44的硅基硬模板之后, C-34和C-44 呈现IV型吸附等温线, 在 $p / p_{0}=0.35$ 出现毛细凝聚突跃, 表明其具有规整的介孔结构. 另外, 无法闭合的滞后环 表明该材料以碳多苯环作为介孔孔壁, 表面性质类似于 FDU-15酚醛树脂介孔聚合物 ${ }^{[23]}$. 同时, 脱除氧化硅后的 C- $x$ 样品存在叠加的双孔径分布, 显示了典型的CMK-5 结构, 即中空碳管的六方密堆积形式: 右边较尖锐的分 布归属于以原先介孔孔道为载体形成的多苯环纳米管 管径; 左边宽泛的分布则认为是管隙, 这取决于SBA-15 母体的孔壁厚度及附着上面的其它物种如 $\mathrm{Al}$ 等 ${ }^{[30]}$ (见图 2(b)). 由表2还可以看出, 样品中随着糠醇负载量的增 加, 中空纳米碳管的孔壁增厚, 从而极大地促进了大分 子在孔道中的传输与扩散.

图3为C-44- $\mathrm{SO}_{3} \mathrm{H}$ 样品的SEM照片. 由图可见, 该样 品具有类似CMK-5的介孔结构: 二维纳米管六方密堆 积排列, 管壁约为 $2 \mathrm{~nm}$, 管隙分布不规整约为 $<4 \mathrm{~nm}$, 并 且在磺化作用后, 该材料结构依然保持完整, 显示了稳 定的机械强度和物化性质.

图4(a)为引入磺酸根的SC-34和C-34的FT-IR谱. 由 图可见, SC-34- $\mathrm{SO}_{3} \mathrm{H}$ 样品在 $1000 \sim 1300 \mathrm{~cm}^{-1}$ 处出现的宽 峰归属于 $\mathrm{Si}-\mathrm{O}$ 的伸缩振动吸收. 脱硅后, 所得 C-34- $\mathrm{SO}_{3} \mathrm{H}$ 相比于未经磺化作用的C-34, 在 $1032 \mathrm{~cm}^{-1}$ 处 出现一个尖锐的吸收峰, 归属于 $\mathrm{S}=\mathrm{O}$ 的对称伸缩振动, 表明 $-\mathrm{SO}_{3} \mathrm{H}$ 基团已成功嫁接到碳多苯环载体上. 另外, C-34- $\mathrm{SO}_{3} \mathrm{H}$ 样品还在约 $1210 \mathrm{~cm}^{-1}$ 处出现了一个较明显的 吸收峰, 归属于 $-\mathrm{COOH}$ 的 $\mathrm{C}=\mathrm{O}$ 伸缩振动, 揭示了磺化作 用同时也催化部分碳氢氧有机物转化为羧酸功能基 团 $^{[24,26]}$.

吡啶吸附FT-IR谱可以直接标定固体酸活性位点的 种类、强度和密度 ${ }^{[31]}$. 将磺化后样品在真空环境中 $150{ }^{\circ} \mathrm{C}$ 下干燥脱水, 再降温到 $110^{\circ} \mathrm{C}$ 吸附吡啶, 为了避免 吡啶的物理吸附最后需要回升到 $150{ }^{\circ} \mathrm{C}$ 进行真空脱附 处理 ${ }^{[6]}$. 图4(b) 为 $\mathrm{SC}-x-\mathrm{SO}_{3} \mathrm{H}$ 系列样品经吡啶吸附后的 FT-IR谱. 可以看出, 在1531 1545, 1489和 $1445 \mathrm{~cm}^{-1}$ 处 
存在明显的吡啶环伸缩振动吸收峰, 分别对应于B酸位、 B酸位和/或 L酸位、 L酸位和/或 $\mathrm{Si}-\mathrm{OH}$. 随着糠醇负载量 的增加, 样品在1531 1545 $\mathrm{cm}^{-1}$ 区域吸收峰强度基本保 持不变; 至 $51 \%$ 时吸收峰强度急剧降低. 这不仅归因于 酸密度增加容易生成氢键, 减弱了吡啶与B酸位的结合, 而且证明了碳多苯环管壁的增厚导致空间位阻增大(见 表2), 减小了吡啶气体分子扩散至可接触酸位的可能性.

\section{2. 催化反应性能}

酸量和比表面积是影响催化剂活性的两个主要因 素, 图5 比较了采用糠醇和蔗糖作填充物的复合固体酸 在环戊酩和乙二醇缩酩反应中的催化活性. 由图可见, 随着有机填充物的增加, 两个固体酸的比表面积均逐渐 降低; 当 $x<35$, 磺酸引入量也持续增加. $x=35$ 时, 蔗糖 作为填充物的复合固体酸的酸值达最高为 $0.70 \mathrm{mmol} / \mathrm{g}$, 而糠醇则在 $x=50$ 时达最高 $0.84 \mathrm{mmol} / \mathrm{g}$. 然而, 后者的 比表面积比前者高出近 $100 \mathrm{~m}^{2} / \mathrm{g}$. 因此, 当 $x=50$ 时, 糠 醇-硅复合固体酸催化的缩酮反应收率达到最高 $(82$ $\mathrm{mol} \%$ ), 而蔗糖-硅材料仅为 $63 \mathrm{~mol} \%$. 研究表明 ${ }^{[6]}$, 蔗糖 作为填充物时, 多苯环的无序堆积容易造成SBA-15孔道 堵塞, 比表面积和孔体积急剧减小, 因此磺酸根的引入 量在 $x=35$ 时出现拐点. 然而, 糠醇则是以均匀涂层的方 式负载在SBA-15孔壁上, 有助于提高多苯环负载量, 促 使较多磺酸基团的取代; 焙烧后的碳多苯环-硅复合材 料呈现稳定的中空纳米管状结构在磺化作用和催化反 应中提供了较大的反应空间, 使可接触酸位增多, 有利 于底物和/或产物在孔道中的充分扩散.

利用不同大分子醛和酮与乙二醇或者丁二醇的缩 酮反应, 我们进一步考察了 $\mathrm{SC}-x-\mathrm{SO}_{3} \mathrm{H}$ 固体酸的催化活 性, 结果列于表 3 , 其中 $\mathrm{SC}-34-\mathrm{SO}_{3} \mathrm{H}$ 因其可观的可接触酸 活性位以及相当大的反应空间被选作目标催化剂. 由表 可见, 当选用乙二醇为醇源时, 戊醛、异丁醛、苯甲醛以 及环已酮的缩合反应收率均在 $90 \%$ 以上, 显示了 $\mathrm{SC}-34-\mathrm{SO}_{3} \mathrm{H}$ 在这类底物反应中的高催化活性(实验 1,3 , 5和7). 当醇源为丁二醇时, 上述各反应收率略降低了约 $5 \%$ 左右(实验 $2,4,6$ 和 8 ). 而选用3-戊酮和二苯甲酩等底
物时, 反应收率也有所下降. 这是由于它们的分子相对 较大, 其扩散受到孔道尺寸的限制; 另一方面, C=O官能 团处于分子中间, 易受两侧支链的位阻影响, 因此反应 物与磺酸酸位接触的可能性减小, 从而导致产物收率下 降(实验9 12). 但是, 比较二苯甲酮与苯甲醛反应结果, 前者与乙二醇充分反应 $5 \mathrm{~h}$ 后, 收率达到 $56 \%$ (实验 5 和 11). 表明SC-34- $\mathrm{SO}_{3} \mathrm{H}$ 样品具有较大的反应空间, 可完全 容纳苯甲醛尺寸大小的底物(实验5), 其反应收率为 $91 \%$. 二苯甲酮刚性体积约为苯甲醛的 2 倍, 同等容积下官能 团数量仅是后者的一半, 因此该催化材料对二苯甲酮与 乙二醇的催化效果也非常明显. 同样, 比较二苯甲酮与 乙二醇和丁二醇的反应结果发现, 后者的收率约为前者 的一半(实验11和12), 这是因为丁二醇体积比乙二醇大 一倍, 能够到达酸位与二苯甲酮反应的数量也减少一半. 结果表明, 拥有数量可观的可触及酸位的 $\mathrm{SC}-34-\mathrm{SO}_{3} \mathrm{H}$ 固 体酸在大分子缩酮反应中表现出较高且稳定的催化活 性.

反应结束后, 过滤 SC-34- $\mathrm{SO}_{3} \mathrm{H}$ 固体酸催化剂, 用过 量环己烷多次充分洗涤并干燥, 用于环己酮和乙二醇的 缩酮反应中考察其重复使用性能. 结果表明, 重复使用 6 次后, 反应收率减少了约 5\%. 这说明SBA-15孔道内壁 富集的Al酸性位以及较低温度下的真空抽取, 使糠醇形 成的碳多苯环层牢固地附着在壁上, 因而表现出较高的 稳定性.

\section{4. 结论}

SBA-15负载的糠醇在 $550^{\circ} \mathrm{C}$ 下不完全焙烧, 可制得 规整的中空管状碳多苯环-硅介孔复合物, 该复合物经 过磺酸作用, 酸量最高可达 $0.84 \mathrm{mmol} / \mathrm{g}$. 相比于蔗糖作 为糖源的复合固体酸, 所制碳多苯环-硅酸催化剂具有 中空碳纳米管堆积的类似CMK-5介孔结构、较大的反应 空间、稳定的机械性能、较高的比表面积以及大量可以 接触的B酸位, 因而在大分子缩醛(酮)反应中表现出很 高的催化性能, 且制备方法简单易于重复使用, 有望在 实际的酸催化反应得到广泛应用. 